\title{
Seroprevalence of Trypanosoma evansi Infection in Water Buffaloes from the Mountainous Region of North Vietnam and Effectiveness of Trypanocidal Drug Treatment
}

\author{
Quoc Doanh NGUYEN ${ }^{1) *}$, Thu-Thuy NGUYEN ${ }^{2,3)}$, Quang Phuc PHAM ${ }^{1)}$, Ngoc My LE ${ }^{1)}$, Giang Thanh T. NGUYEN ${ }^{1)}$ \\ and Noboru INOUE ${ }^{3}$ \\ ${ }^{1)}$ Laboratory of Parasitology, National Institute of Veterinary Research, 86 Truong Chinh, Hanoi, Vietnam \\ ${ }^{2)}$ Department of Veterinary Public Health, Faculty of Veterinary Medicine, Hanoi University of Agriculture, Trau Quy, Gialam, Hanoi, \\ Vietnam \\ ${ }^{3)}$ National Research Center for Protozoan Diseases, OIE Reference Laboratory for Surra, Obihiro University of Agriculture and \\ Veterinary Medicine, Hokkaido 080-8555, Japan
}

(Received 7 December 2012/Accepted 23 April 2013/Published online in J-STAGE 10 May 2013)

\begin{abstract}
Water buffalo (WB) is an important domestic animal in Vietnam. This study utilized a card agglutination test to investigate seroprevalence of surra in WB population. Sera were collected from $585 \mathrm{WB}$ from 4 different regions in Cao Bang and Thai Nguyen Provinces. Among them, 131 samples (22.4\%) were positive for surra. The highest prevalence (24.6\%) was found among 3 to 5 years old WB. Buffaloes less than 3 years old had the lowest prevalence (15.6\%). Among 27 abortion cases, 9 WB (33.3\%) were surra positive. For treatment of surra, Berenil ${ }^{\circledR}$ demonstrated a $100 \%$ cure rate, while that of Trypamidium ${ }^{\circledR}$ was only $40 \%$. Our findings suggest that the current control strategy has not succeeded in reducing prevalence of surra in Vietnam.
\end{abstract}

KEY WORDS: eroprevalence, surra, treatment, Vietnam, water buffalo.

doi: 10.1292/jvms.12-0533; J. Vet. Med. Sci. 75(9): 1267-1269, 2013

Trypanosoma evansi is a hemoparasite, belonging to the genus Trypanosoma and subgenus Trypanozoon [9]. The parasite causes a disease called surra to various species of animals. In Vietnam, surra was first described by Blanchard in 1886, and throughout the 20th century, many serious outbreaks of surra in water buffaloes have been reported $[12,14]$. The control program for surra in the water buffalo population requires updated data obtained from epidemiological studies. A good understanding on the occurrence of the disease would guide veterinary officers and policy makers to implement a better preventative and treatment program [6]. However, there is a lack of information on the current prevalence and distribution of $T$. evansi infection in Vietnam, since the last surveys were completed in 1998 and 2000 [5, 14, 15]. Aside from epidemiological studies, chemotherapy administration is another aspect of disease control. In Vietnam, 2 of the most common drugs prescribed are Trypamidium ${ }^{\circledR}$ (isometamidium chloride) from Merial, France and Berenil ${ }^{\circledR}$ (diminazene aceturate) from Intervet, Germany. According to McDermott et al. [11] and Zhou et al. [16], extensive use of these 2 compounds has led to drug resistance and treatment failure in several countries. Thus, there is a need to evaluate current surra treatment by assessing the effectiveness of Trypamidium ${ }^{\circledR}$ and Berenil ${ }^{\circledR}$ under

*Correspondence to: NGuYen, Q. D., Laboratory of Parasitology, National Institute of Veterinary Research, 86 Truong Chinh, Dong $\mathrm{Da}$, Hanoi, Vietnam.

e-mail: ngthu83thuy@gmail.com

(C)2013 The Japanese Society of Veterinary Science in vivo conditions.

Following on from the surveys of Thu et al. [14] and Holland et al. [5], this paper reports the current seroprevalence of surra among water buffaloes in the mountainous region of North Vietnam and the effectiveness of 2 available trypanocidal drugs $\left(\right.$ Trypamidium $^{\circledR}$ and Berenil ${ }^{\circledR}$ ). The study area was in the Cao Bang and Thai Nguyen Provinces in Northern Vietnam, which have a high population of water buffaloes and are known to be endemic for surra (Fig. 1). The sample sites were located at an average altitude of 200 $\mathrm{m}$. Average temperature is $27 \pm 2^{\circ} \mathrm{C}$ during the rainy season and approximately $10 \pm 1^{\circ} \mathrm{C}$ during the dry season. Field sampling was carried out during the dry season, from September to November 2010. From each province, 2 regions were chosen at random. In those regions, farmers were asked to bring their buffaloes to a local veterinary center for blood sampling. In cases where the number of buffaloes sampled was less than $50 \%$ of the animal population, blood collection was also performed at the farms chosen from the absent list. In total, 585 water buffaloes from 4 regions were examined in the study. Information on each animal including the address, age (provided by the owner), clinical signs and history of abortion was recorded. A maximum of $10 \mathrm{~m} l$ blood was collected from the jugular vein of the animal and kept at room temperature for clotting, followed by centrifugation $(1,000 \times \mathrm{g}, 10 \mathrm{~min})$ to obtain serum. Serum samples were examined by using card agglutination test (CATT/T. evansi) (Antwerp, Belgium). The test procedure followed the FAO and OIE manual for serological diagnosis of surra $[4,13]$.

For evaluation of trypanocidal drug effectiveness, 10 healthy water buffaloes purchased from non-endemic areas 

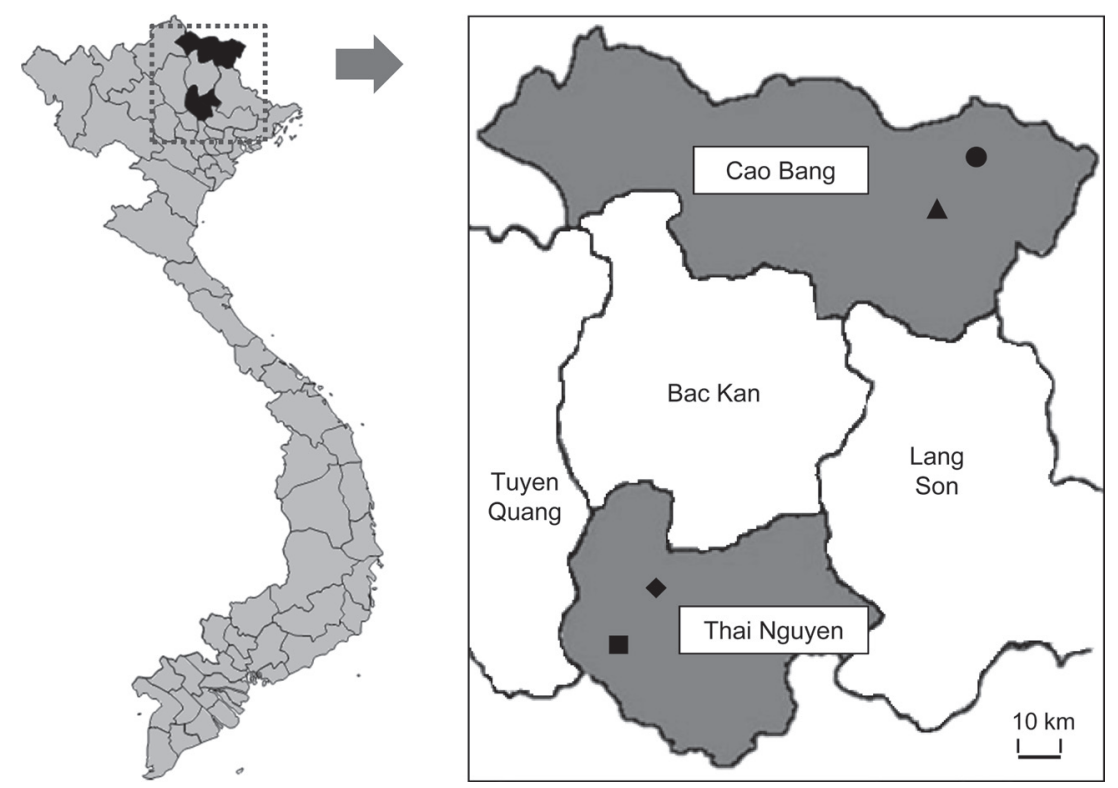

Fig. 1. Map of Vietnam showing the locations of 4 sample sites (•Trung Khanh, $\Delta$ Quang Uyen, Phu Luong and $\mathbf{m D a i} \mathrm{Tu}$ ) surveyed in Cao Bang and Thai Nguyen Provinces. Blood samples were collected from a total of 585 water buffaloes in these regions from September to December 2010.

Table 1. Prevalence of Trypanosoma evansi infection in water buffaloes $(n=585)$ surveyed in 4 regions of North Vietnam

\begin{tabular}{ccccc}
\hline Region & $\begin{array}{c}\text { Number } \\
\text { of serum } \\
\text { samples }\end{array}$ & $\begin{array}{c}\text { Number } \\
\text { of posi- } \\
\text { tive serum } \\
\text { samlpes a) }\end{array}$ & $\begin{array}{c}\text { Prevalence } \\
(\%)\end{array}$ & $\begin{array}{c}\text { Significant } \\
\text { difference } \\
P \text { value b) }\end{array}$ \\
\hline Trung Khanh & 160 & 37 & 23.1 & 0.95 \\
Quang Uyen & 145 & 34 & 23.4 & 0.77 \\
Phu Luong & 150 & 33 & 22 & 0.8 \\
Dai Tu & 130 & 27 & 20.8 & 0.63 \\
\hline Total & 585 & 131 & 22.4 & \\
\hline
\end{tabular}

a) As determined using the Card Agglutination Test for surra.

b) $P$ values $>0.05$ showed no significant difference in the prevalence of T. evansi infection in the 4 different sample sites.

were confirmed negative with surra through parasitological tests, mouse inoculation and CATT/T. evansi. Each buffalo was infected with $10^{6} T$. evansi(Vietnamese strain) by intravenous injection. Using microscopy, parasitemia was detected from peripheral blood of infected buffaloes 2 weeks after infection. One month after the experimental infection, 5 buffaloes were treated with Trypamidium ${ }^{\circledR}(1$ $\mathrm{mg} \mathrm{kg}{ }^{-1}$ bw in dose, intramuscular injection). The other 5 buffaloes received Berenil ${ }^{\circledR}$ treatment $\left(3.5 \mathrm{mg} \mathrm{kg}^{-1} \mathrm{bw}\right.$ in dose, intramuscular injection). Clearance of parasitemia in experimentally infected buffaloes was assessed through parasitological tests, and mouse inoculation at 2, 4, 6 and 8 weeks post-treatment. Mouse inoculation and parasitological tests were conducted as described in the OIE manual for di-
Table 2. Prevalence of Trypanosoma evansi infection in water buffaloes at different ages $(\mathrm{n}=585)$

\begin{tabular}{ccccc}
\hline $\begin{array}{c}\text { Age of water } \\
\text { buffalo } \\
\text { (years) }\end{array}$ & $\begin{array}{c}\text { Number } \\
\text { of serum } \\
\text { samples }\end{array}$ & $\begin{array}{c}\text { Number } \\
\text { of posi- } \\
\text { tive serum } \\
\text { samples }^{\text {b) }}\end{array}$ & $\begin{array}{c}\text { Prevalence } \\
(\%)\end{array}$ & $\begin{array}{c}\text { Correlation } \\
\text { coefficient } \\
\mathrm{r}\end{array}$ \\
\hline$<3$ & 122 & 19 & 15.6 & - \\
$3-5$ & 171 & 42 & 24.6 & 1 \\
$5-8$ & 170 & 47 & 27.6 & 0.92 \\
$>8$ & 122 & 23 & 18.9 & 0.42 \\
\hline Total & 585 & 131 & 22.4 & \\
\hline
\end{tabular}

a) Provided by the owners of the water buffaloes.

b) As determined using the Card Agglutination Test for surra.

agnosis of T. evansi infection [13]. Results were statistically analyzed by using the method described by Collett (2003) [1] and online software (http://ncalculators.com/statistics/ correlation-coefficient-calculator.htm).

Results showed that $22.4 \%$ (131) water buffaloes were positive for $T$. evansi infection (Table 1). The prevalence ranged from $20.8 \%$ to $23.4 \%$ and was not significantly different $(P>0.05)$ between the 4 regions. As for the age, the highest number of positive buffaloes was the 5-8 years old (27.6\% prevalence). In contrast, young water buffaloes $(<3$ years old) showed the lowest number of positive cases at $15.6 \%$ (Table 2). There was a strong positive correlation $(\mathrm{r}=0.92, P<0.05)$ between the age of buffalo (up to 8 years old) and surra prevalence, which is similar to a previous study in Indonesia [3]. This could be explained by the dura- 
tion of time in which the animals were exposed to the disease vectors. Adult buffaloes graze outside or work in the fields most of the time and therefore have a greater chance of being bitten by blood sucking flies. However, we do not know why the number of surra-positive elder buffaloes ( $>8$ years old) was lower. To address this question, further research would be required. From a total of 27 water buffaloes that had recently aborted in the 4 sample sites, $33.3 \%$ were positive with $T$. evansi infection, and the infection rate varied from $25.0 \%$ to $42.9 \%$ (data not shown). Besides T. evansi infection, other causes of abortion in water buffaloes may include tuberculosis, brucellosis and some physical accidents which are commonly seen in the highland area [2]. These findings suggest a potential correlation between abortion and surra in water buffaloes and may encourage more studies on the causes of abortion and statistical evidence of the correlation in future. In 2 groups of water buffaloes treated separately with Trypamidium ${ }^{\circledR}$ and Berenil ${ }^{\circledR}$, parasite clearance was achieved after 2, 4 and 6 weeks post-treatment. However, at week 8,3 buffaloes in the Trypamidium ${ }^{\circledR}$ group displayed $T$. evansi infection relapse as detected by the mouse inoculation method. In the group treated with Berenil ${ }^{\circledR}$, no positive cases were detected throughout the 8 weeks post-treatment. The cure rates for Trypamidium ${ }^{\circledR}$ and Berenil ${ }^{\circledR}$ treatments were $40 \%$ and $100 \%$, respectively. This finding would be helpful information for veterinarians when deciding on what drug to prescribe.

Our results revealed that for over 10 years, since the last survey carried out in North Vietnam, the prevalence of surra has not been decreasing. This implies that the current disease control program has not been apparently effective. It mainly depends on a regimen involving both treatment and prevention. Farmers are instructed to kill biting flies around an animal's shelter with insecticides, followed by improvement of animal diet and working condition. However, a new plan needs to be in place to better control surra. Vaccine against T. evansi infection is not currently available. While Berenil ${ }^{\circledR}$ demonstrated higher effectiveness than Trypamidium ${ }^{\circledR}$ in this study, other trypanocidal drugs have been found to be ineffective due to drug resistance of the parasite and/or toxicity to the animal host $[7,8,12,16]$. Therefore, alternative strategies should focus extensively on vector control activities. It might be good to implement the approaches being used by utilization of fly traps or screens and combination with insecticide spraying and environmental modification. Those methods have been utilized to control tsetse fly successfully in Africa [10]. In addition, regular surveillance of surra prevalence is also crucial to control the disease.

ACKNOWLEDGMENTS. The study was financially supported in part by the Vietnamese Ministry of Agriculture and Rural Development. The authors thank Thu Thuy Do, Van Anh and Hoan Doan for their technical assistance and Martin O'Brien for critical reading of the manuscript.

\section{REFERENCES}

1. Collett, D. 2003. p. 24. Modeling Binary Data, 2nd ed., Chapman and Hall/CRC, Boca Raton.

2. Council, N. R. 1981. The Water Buffalo: New Prospects for an Under-Utilized Animal. National Academy Press, Washington D.C.

3. Davison, H. C., Thrusfield, M. V., Husein, A., Muharsini, S., Partoutomo, S., Rae, P. and Luckins, A. G. 2000. The occurrence of Trypanosoma evansi in buffaloes in Indonesia, estimated using various diagnostic tests. Epidemiol. Infect. 124: 163-172. [Medline] [CrossRef]

4. FAO A field guild for diagnosis, treatment and prevention of African animal trypanosomosis [cited 2012 December 5]. Available from http://www.fao.org/DOCREP/006/X0413E/X0413E00. HTM.

5. Holland, W. G., Thanh, N. G., My, L. N., Do, T. T., Goddeeris, B. M. and Vercruysse, J. 2004. Prevalence of Trypanosoma evansi in water buffaloes in remote areas in Northern Vietnam using PCR and serological methods. Trop. Anim. Health Prod. 36: 45-48. [Medline] [CrossRef]

6. Jesser, P., Markula, A. and Csurhes, S. 2008. Pest Animal Risk Assessment: Water Buffalo Bubalus bubalis [cited 2012 December 5]. Available from http://www.daff.qld.gov.au/documents/ Biosecurity_EnvironmentalPests/IPA-Water-Buffalo-RiskAssessment.pdf.

7. Kinabo, L. D. 1993. Pharmacology of existing drugs for animal trypanosomiasis. Acta Trop. 54: 169-183. [Medline] [CrossRef]

8. Le, N. M., Wuyts, N., Luckins, A. G., Nguyen, A. D. and Nguyen, T. G. 1998. Drug sensitivity of Trypanosoma evansi and the use of immunoassays in diagnosing infections with $T$. evansi in buffaloes in Vietnam. Ann. N Y. Acad. Sci. 849: 188-194. [Medline] [CrossRef]

9. Luckins, A. G. and Dwinger, R. H. 2004. Non-tsetse-transmitted Animal Trypanosomiasis. pp. 269-279. In: The Trypanosomiasis (Maudlin, I. Holmes, P. H. and Miles, M. A. eds.), CABI Publishing, Oxfordshire.

10. Malvy, D. and Chappuis, F. 2011. Sleeping sickness. Clin. Microbiol. Infect. 17: 986-995. [Medline] [CrossRef]

11. McDermott, J., Woitag, T., Sidibé, I., Bauer, B., Diarra, B., Ouédraogo, D., Kamuanga, M., Peregrine, A., Eisler, M., Zessin, K. H., Mehlitz, D. and Clausen, P. H. 2003. Field studies of drugresistant cattle trypanosomes in Kénédougou Province, Burkina Faso. Acta Trop. 86: 93-103. [Medline] [CrossRef]

12. My, L. N., Thu, L. T., Lan, P. D., Lang, P. S. and Phuc, D. V. 1998. Trypanosoma evansi and trypanosomosis in Vietnam. $J$. Protozool. Res. 8: 171-176.

13. OIE 2010. Trypanosoma evansi infections (including surra). pp. 352-360. In: Manual of Diagnostic Tests and Vaccines for Terrestrial Animals, 6th ed., OIE, Paris.

14. Thu, L. T., My, L. N., Lan, D. P., Lang, S. P., Phuc, V. D. and Doanh, P. Q. 1998. Epidemiological survey on Trypanosoma evansi infection in Vietnam. J. Protozool. Res. 8: 177-181.

15. Verloo, D., Holland, W., My, L. N., Thanh, N. G., Tam, P. T., Goddeeris, B., Vercruysse, J. and Büscher, P. 2000. Comparison of serological tests for Trypanosoma evansi natural infections in water buffaloes from north Vietnam. Vet. Parasitol. 92: 87-96. [Medline] [CrossRef]

16. Zhou, J., Shen, J., Liao, D., Zhou, Y. and Lin, J. 2004. Resistance to drug by different isolates Trypanosoma evansi in China. Acta Trop. 90: 271-275. [Medline] [CrossRef] 